\title{
Fairly Bad
}

National Cancer Institute

\section{Source}

National Cancer Institute. Fairly Bad. NCI Thesaurus. Code C121635.

An indication that something has little quality, value or worth. 